\title{
INVESTIGATION OF THE INFLUENCE OF ANTIOXIDANT COMPOSITIONS ON DEVELOPMENT OF MICROBIOLOGICAL SPOILAGE IN STORAGE OF FRUITS
}

\author{
Marina Serdyuk \\ Department of technology of processing and \\ storage of agricultural products \\ Tavria State Agrotechnological University
}

18 B. Khmelnitsky ave., Melitopol, Zaporizhia region, Ukraine, 72312 igorserduk@mail.ru

\section{Dmytro Stepanenko}

Departmento of «Ecology and Zoology»

Melitopol State Pedagogical University named after Bohdan Khmelnytsky

20 Lenin str., Melitopol, Zaporizhia region., Ukraine, 72313

asija-2008@mail.ru

\section{Olesia Priss}

Department of technology of processing and storage of agricultura lproducts

Tavria State Agrotechnological University

18 B. Khmelnitsky ave., Melitopol, Zaporizhia region, Ukraine, 72312 olesyapriss@gmail.com

\section{Tatiana Kopylova}

Department of «Ecology and Zoology»

Melitopol State Pedagogical University named after Bohdan Khmelnytsky

20 Lenin str., Melitopol, Zaporizhia region., Ukraine, 72313

asija-2008@mail.ru

\section{Nonna Gaprindashvili}

Department of technology of processing and storage of agricultural products

Tavria State Agrotechnological University

18 B. Khmelnitsky ave., Melitopol, Zaporizhia region, Ukraine, 72312 nonnagap@mail.ru

\section{Alina Kulik}

Department of technology of processing and storage of agricultural products

Tavria State Agrotechnological University

18 B. Khmelnitsky ave., Melitopol, Zaporizhia region Ukraine, 72312 alina_potapenko@ukr.net

\section{Vita Atanasova}

Department of restaurant and health promoting catering

Odessa National Academy of Food Technologies

112 Kanatna str., Odessa, Ukraine, 65039

a-vita@mail.ru 


\author{
Maryana Kashkano \\ Department of restaurant and health promoting catering \\ Odessa National Academy of Food Technologies \\ 112 Kanatna str., Odessa, Ukraine, 65039 \\ marykash@ukr.net \\ Julia Kozonova \\ Department of restaurant and health promoting catering \\ Odessa National Academy of Food Technologies \\ 112 Kanatna str., Odessa, Ukraine, 65039 \\ kozonova5@gmail.com
}

\begin{abstract}
The studies are devoted to the scientific grounding of expedience of after-harvest processing by antioxidant compositions for preventing the development of pathogenic microflora on fruit surfaces during a long storage. For the studies were used apple fruits of the varieties Aidared, Golden Dushesse, Renet Simirenka, pear fruits of the varieties Victoria, Crimea Raisin and Cure, plum fruits of the varieties Voloshka, Stanley and Italian Ugorka. Fruits were processed by immersion in the following antioxidant compositions: ACM is a mixture of dimethyl sulfoxide, ionol and polyethylene glycols; AARL - mixture of ascorbic acid, routin and lecithin; DL - mixture of dimethyl sulfoxide, ionol and lecithin. Fruits, processed by water, were used as a control. Exposition - 10 seconds. Storage was carried out at the temperature $0 \pm 1{ }^{\circ} \mathrm{C}$, relative air humidity $90-95 \%$. It was established that in the period of fruits laying for storage, the mean amount of epiphyte microflora was fixed on surfaces of plump and pear fruits of the mean ripening term. In the variety composition of epiphyte microflora prevailed spores of mesophyl aerobic and facultative-anaerobic microorganisms. Their mean number on apple fruits surface was $9,6 \cdot 10^{3} \mathrm{CCU} / \mathrm{g}$, pear fruits $-10,610^{3} \mathrm{CCU} / \mathrm{g}$, plump fruits $-18 \cdot 10^{3 \mathrm{C}} \mathrm{CCU} / \mathrm{g}$. AOC processing of all types of fruits essentially decreased the speed of both MAFAnM and micromycetes growth. It was demonstrated that the used compositions in 2...3,5 times decreased the level of day losses from microbiological spoilage during the whole storage period. The most positive effect was received at using compositions, based on dystinol and lecithin. Multifactor analysis determined that the level of day losses from microbiological spoilage was mainly influenced by factors of raw material variety features (factor A) and antioxidant compositions processing (factor D). The shares of influence are 24 and $21 \%$ respectively.

Keywords: apple fruits, pear fruits, plump fruits, dimethyl sulfoxide, ionol, polyethylene glycols, after-harvest processing,
\end{abstract} fungal molds.

\title{
1. Introduction
}

Fresh fruit products are considered as the main component of human functional nourishment. Their consumption must be even during a whole year [1]. But fruits can be received directly from a garden only during $3 . .4$ months [2]. So, the question of their long storage regulation gains a specific priority.

The main problem that appears at fruit raw material storage is a loss of commodity qualities as a result of affection by fungal moulds. At that the level of products losses may reach $23 \%$ [3].

The affection degree and the speed of pathogenic microflora development on fruits surface is determined by many factors. The mains ones are considered as the level of infectious load and variety and specific immunity. The important factors are cultivation and transportation technologies [4]. The essential influence is caused by weather conditions at cultivation and harvesting [5]. At the long storage the main factor is a way and regime of storage [6].

For decelerating microbiological spoilages development and shortening fruit products losses during storage there are many diverse technological arrangements. The most spread one is the storage in the regulated and modified gas atmosphere [7, 8]. Among physical methods may be used ozonization, ionization, radiation processing [9]. The spread method is also the use of different food covers [10].

But the elaborated methods of fruit products protection from fungal spoilages don't find wide use in industry that is connected with their complication, high cost and ecological safety. 
So, the most important question of shortening of fruit products losses from microbiological spoilages development remains urgent and needs additional studies.

With regard to this fact, the studies realized by the authors, were aimed at the scientific grounding of expedience of after-harvest processing by antioxidant compositions for preventing the development of pathogenic microflora on fruit surfaces during a long storage.

\section{Materials and Methods}

For the studies were used apple fruits of the varieties Aidared, Golden Dushesse, Renet Simirenka, pear fruits of the varieties Victoria, Crimea raisin and Cure, plum fruits of the varieties Voloshka, Stanley and Italian Ugorka.

Fruits were processed by immersion in antioxidant compositions (AOC) by four variants.

Variant 1 - ACM - mixture of dimethyl sulfoxide, ionol and polyethylene glycols;

Variant 2 - AARL - mixture of ascorbic acid, routin and lecithin;

Variant 3 - DL - mixture of dimethyl sulfoxide, ionol and lecithin;

Variant 4 - control (C) - fruits, processed by water.

Exposition - 10 seconds. Repetition of a variant - fivefold. The mass of one repetition was $25 \mathrm{~kg}$.

Storage was realized at regime parameters, optimal for studied varieties: temperature $0 \pm 1{ }^{\circ} \mathrm{C}$, relative air humidity $90-95 \%$.

For elimination of microorganisms of different taxonomic groups from product surfaces, samples were selected at products laying for storage, after AOC processing and after the storage end.

In the process of microbiological control were determined: the general number of mesophyl aerobic and facultative-anaerobic microorganisms (MAFAnM) according to SSTC 8446:2015, the general number of mould fungi - according to SSTC 8447:2015.

Samples from fruit products with the round form are cut spike-like by a knife. The determination of microbial pollution of surfaces of received fruit samples is carried out by washout using a wadding tampon. A sterile wadding tampon is moistened by peptone-water solution and surfaces of prepared pieces of analyzed fruits with general area $100 \mathrm{~cm}^{2}$ are wet by it. A tampon is placed in a test-tube with $10 \mathrm{~cm}^{3}$ of peptone-saline solution. The content of a test-tube is carefully mixed using a sterile pipette. The received suspension is considered as an initial solution. The further secondary solution is prepared of one share of the initial one and nine shares of peptone-saline solution by mixing in the test-tube. The third and following solutions are prepared in an analogous way. In total, a series of tenfold solutions is prepared. The time interval between product sample preparation, washing of microflora off from its surface and inoculation for nutritive mediums must not exceed 30 minutes.

At determining MAFAnM number the nutritive medium of dry nutritive agar $\mathrm{D}$ with leaven extract was used. From each solution $1 \mathrm{~cm}^{3}$ was transferred on bottoms of two parallel sterile Petri dishes. Petri dishes with the inoculation material were added with $10-15 \mathrm{~cm}^{3}$ of nutritive medium, preliminary melt and cooled to the temperature $40 \ldots 45^{\circ} \mathrm{C}$ and mixed by cautious turns at a closed coat for inoculation material is distributed evenly among the whole nutritive medium. In further, the dishes were filled with a second layer - famine agar.

The inoculations were incubated at the temperature $(30 \pm 1){ }^{\circ} \mathrm{C}$ during $(72 \pm 3)$ hours in aerobic conditions.

After inoculations incubation the number of colonies, grown on Petri dishes was calculated. For the calculation were selected Petri dishes that from 15 to 300 had grown on (Fig. 1).

At the determination of mould fungi, the nutritive medium, agarized by an antibiotic, was prepared directly before use. In the experiments was used an antibiotic solution with mass concentration of gentamicin sulfate $10 \mathrm{~g} / \mathrm{dm}^{3}$. A flask with $80 \mathrm{mg}$ of gentamicin sulfate was added with $8 \mathrm{~cm}^{3}$ of sterile distilled water. The content of the flask was dissolved. $895 \mathrm{~cm}^{3}$ of the base was added with $5 \mathrm{~cm}^{3}$ of gentamicin solution with mass concentration $10 \mathrm{~g} / \mathrm{cm}^{3}$.

The medium base was prepared as following: 40,0 of glucose, 10,0 $\mathrm{g}$ of peptone, 18,0 $\mathrm{g}$ of agar were added to $1 \mathrm{dm}^{3}$ of distilled water. The mixture was heated, by periodically stirring it, up to components melting, cooled to $45 \ldots 55^{\circ} \mathrm{C}$, poured out in volumetric flasks and sterilized for $15 \mathrm{~min}$ at the temperature $121 \pm 1^{\circ} \mathrm{C}$. $\mathrm{pH}$ was set in such a way that after sterilization it 
was $6,5 \pm 0$ at $125^{\circ} \mathrm{C}$ Then it was cooled to $48^{\circ} \mathrm{C}$ and added with the antibiotic solution, poured out in Petri dishes in a layer $0,3 \ldots 0,5 \mathrm{~cm}$.

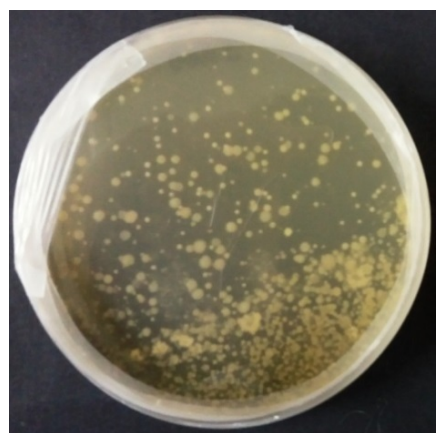

a

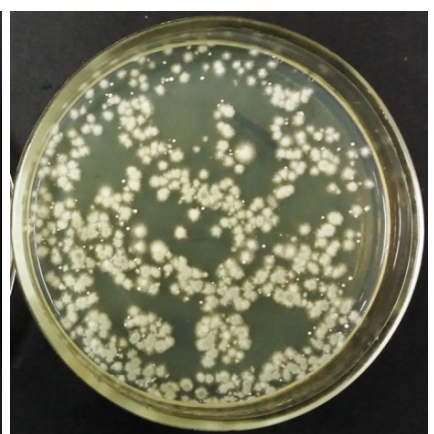

b

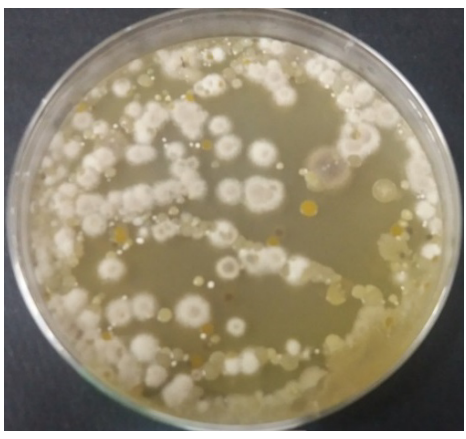

$c$

Fig. 1. MAFAnM on nutritive solution at 3 day of incubation at temperature $30 \pm 1^{\circ} \mathrm{C}$ ): $a$-washouts from apples fruits, $b$ - washouts from plump fruits, $c$ - washouts from pear fruits

The prepared solutions were inoculated in parallel in two Petri dishes. Inoculations were poured out with agarized nutritive medium, melt and cooled to the temperature $45 \pm 1{ }^{\circ} \mathrm{C}$. Inoculations on Petri dishes (turned bottom up) were incubated at the temperature $24 \pm 1{ }^{\circ} \mathrm{C}$ during 5 days. The development of mould fungi on nutritive mediums is associated with mycelium of different coloration (Fig. 2).

For the quantitative calculation there were selected dishes that from 5 to 50 colonies of mould fungi had grown on.

The microscopy of cultivated microorganisms was carried out by the methods of squashed and suspended drop at magnitude 150 and 600 times, microphotos were made using the light microscop GRANUM (China) 3002 and photo camera DCM 130E.

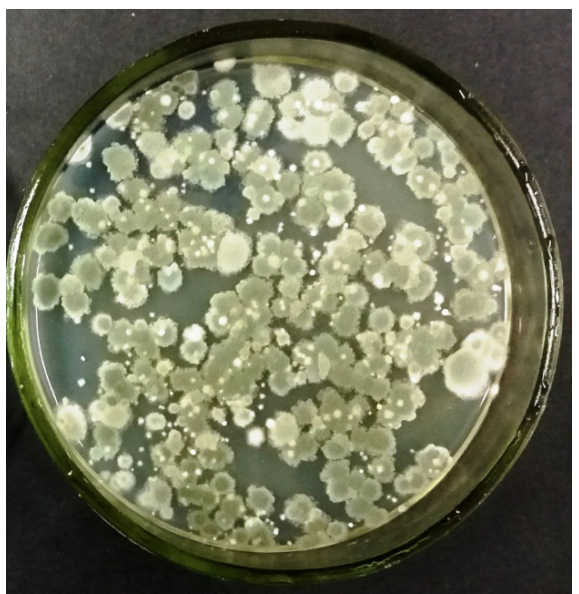

$a$

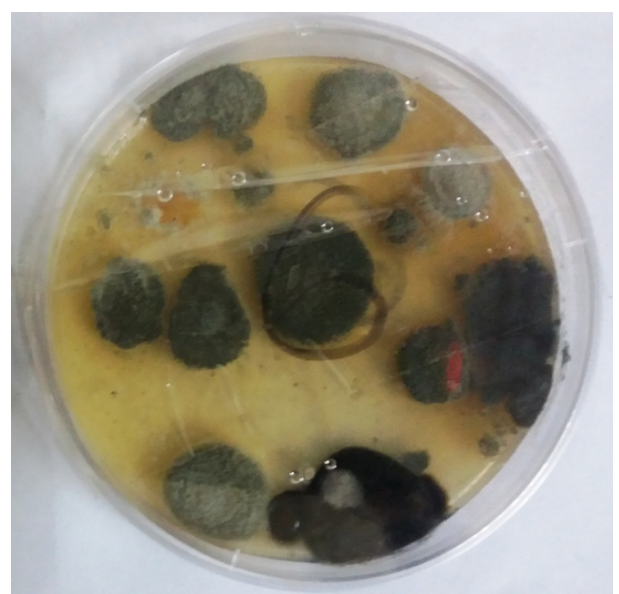

$b$

Fig. 2. Development of mould fungi on nutritive mediums at 6 day of incubation at the temperature $24-26^{\circ} \mathrm{C}: a$-development of Penicillium mycelium,

$b$-development of Alternaria mycelium

The number of fruits, affected by spoilages at storage was determined by standard methods [11]. The processing and analysis of experimental data were carried out using standard methods of variational statistics with "MSoffice Excel 2007" computer program, "Statistica 6" package and a personal computer. 


\section{Results}

In the period of fruits laying for storage, the mean amount of epiphyte microflora was fixed on surfaces of plump and pear fruits of the mean ripening term. In the variety composition of epiphyte microflora prevailed spores of mesophyl aerobic and facultative-anaerobic microorganisms. Their mean amount on apple fruits surface was $9,6 \cdot 10^{3} \mathrm{CCU} / \mathrm{g}$, pear fruits $-10,610^{3} \mathrm{CCU} / \mathrm{g}$, plump fruits $-18 \cdot 10^{3 \mathrm{C}} \mathrm{CCU} / \mathrm{g}$.

The processing of all fruits varieties by antioxidant compositions ACM (variant 1) and DL (variant 3) decreased in the speed of MAFAnM growth 2...13 times and the speed of micromycetes growth - in $1,2 \ldots 11$ times.

The use of ACRL composition decreased the speed of MAFAnM growth in 3,7...20 times, but didn't influence and in research years, characterized by unfavorable weather conditions, even favored micromycetes development. It may be connected with the fact that AOC include lecithin that is considered as a nutritive medium for cultivation of several species of microorganisms. At the end of storage the amount of fungal microflora on pomes at ACRL processing 1,8 times exceeded parameters, established by the standard. At that micromycetes growth was observed only at the last month of storage, when the active processes of fruits overripening took place and their immune features were essentially weakened. At the end of storage of plump fruits in such variant the number of micromycetes didn't exceed parameters, established by the standard.

It must be noted that at storage of control variants of fruits the growth of epiphyte microflora amount began already after $20 . .60$ days of storage.

After the qualitative analysis of epiphyte microflora the dominant fungal microflora was indentified. Fungal microflora of Penicillium, Alternaria, Gloeosporium, Botrytis generi occurred on pomes more often. On plump fruits - Monili and Penicillium generi.

As a result of the aforesaid microflora development, on apple and pear fruit surfaces were revealed such microbiological spoilages as penicilliosis, anthracosis, alternariosis, monilia, botrytis.

On plump fruits most often developed a grey fruit rottenness, which causative agent is MoniliacinereaBonord fungal flora, monilia, caused by Moniliafructigenapers and grey mouldlike rottenness - its agent is Penicilliumexpansum (Lk.) Thom.

The used antioxidant compositions in 2...3,5 times decreased the level the level of day losses from microbiological spoilage during the whole storage period. The most positive effect at storage of all fruit varieties was received at using DL (variant 3) and ACM (variant 1) compositions.

\section{Conclusions}

The realized studies confirm the effectiveness of using ACM and DL antioxidant compositions for shortening day losses as a result of fungal moulds development.

The important positive result of using this storage technology is an increase of fruit raw material storage life and maximal saving of its qualitative parameters.

Despite the fact, that the use of ACRL antioxidant composition stimulated penicilliosis and botrytis development, the first signs of a spoilage appeared on pome surfaces only after 180-210 day and plump fruits - 100 days of storage. Alongside with it, the development of microbiological spoilages on control fruits started already after 20 days of storage.

The inclusion of dimethyl sulfoxide that has not only antioxidant but also bactericidal properties in DL compostion allowed to level the growth-stimulating effect of lecithin. And as a result the most positive effect was received at using this composition.

So, the received data and their scientific substantiation allow to recommend producers to carry out fruits processing by antioxidant composition that includes ionol, dimethyl sulfoxide and lecithin before their further storage.

All components of antioxidant composition in used concentrations are completely safe, eco-friendly and allowed for the use in food and medical industry.

The main causes of fruit products losses at storage are not only microbiological spoilages but also natural losses of mass. So, in our further studies it is expedient to investigate the influence of antioxidant compositions on the general volume of losses at refrigeratory storage. 


\section{References}

[1] Myagerdichev, E. Ya. (2000). Plodoovoschnaya promyishlennost na rubezhe vekov, Pischevaya promyishlennost, 7, 49.

[2] Barth, M., Hankinson, T. R., Zhuang, H., Breidt, F. (2009). Microbiological Spoilage of Fruits and Vegetables. Compendium of the Microbiological Spoilage of Foods and Beverages, 135-183. doi: 10.1007/978-1-4419-0826-1_6

[3] Serdyuk, M. E., Baiberova, S. (2016). Vpliv abIotichnih faktorIv na rozvitok fIzIologIchnih rozladIv ta mIkrobIologIchnih zahvoryuvan pId chas holodilnogo zberigannya plodiv yabluni. PratsI Tavriyskogo derzhavnogo agrotehnologichnogo universitetu, 16 (1),192-203.

[4] Brackett, R. E. (1987). Microbiological consequences of minimally processed fruits and vegetables. Journal of Food Quality, 10 (3), 195-206. doi: 10.1111/j.1745-4557.1987.tb00858.x

[5] Serdyuk, M. Ye., Bajbyerova, S. S. (2015). Oky`sny`j stres i anty`oksy`dantna sy`stema zaxy`stu plodiv yabluni. Xarchova nauka ta texnologiya, 9 (2), 79-85

[6] Serdyuk, M., Stepanenko, D., Baiberova, S., Gaprindashvili, N., Kulik, A. (2016). Substantiaton of selecting the method of pre-cooling of fruits. Eastern-European Journal of Enterprise Technologies, 4 (11 (82)), 62. doi: 10.15587/1729-4061.2016.76235

[7] Juhneviča, K., Skudra, G., Skudra, L. (2011). Evaluation of microbiological contamination of apple fruit stored in a modified atmosphere. Environmental and Experimental Biology, 9, 53-59.

[8] Jacxsens, L., Devlieghere, F., Van der Steen, C., Debevere, J. (2001). Effect of high oxygen modified atmosphere packaging on microbial growth and sensorial qualities of fresh-cut produce. International Journal of Food Microbiology, 71 (2-3), 197-210. doi: 10.1016/s0168-1605(01)00616-x

[9] Stepanenko, D. S. Tarusova, N. V., Gogunskaya, P. V. (2012). Mikrobiologicheskie aspektyi hraneniya svezhih plodov, obrabotannyih elektroionizirovannyim vozduhom. Biologichniy visnik Melitopolskogo pedagogichnogo universitetu imeni Bogdana Hmelnitskogo, 1, 143-152.

[10] Priss, O. Zhukova, V., Bandura, I. (2015). Mikrobiologichni xvoroby pry zberiganni plodovyx ovochiv. Prodovol'cha industriya APK, 5, 35-38.

[11] Najchenko, V. M., Zamors'ka, I. L. (2010). Tehnologija zberigannja i pererobki plodiv ta ovochiv. Uman'.: vidavec' «Sochins'kij», 327. 